\title{
Ötvenhét mappa
}

\section{Egy kínai sibe autodidakta történész, Guan Wenming családfagyüjteménye ${ }^{1}$}

\section{Bevezetés}

A sibék (kín. xibo 锡伯) ${ }^{2}$ a Kínai Népköztársaság (kín. Zhonghua Renmin Gongheguo 中华人民共和国) hivatalosan számon tartott 56 etnikus csoportja közé tartoznak. Nyelvük a tunguz nyelvek egyikeként szoros rokonságot mutat a mandzsu nyelvvel. ${ }^{3}$ Társadalomszerkezetük hagyományosnak tekinthető, funkcionális alapegysége a patrilineáris ágazat, a gargan (kín. zhi 支). Ezek az azonos névvel megnevezett, exogám, szolidáris, rituális csoportok, amelynek tagjai kimutathatóan közös östöl származnak, nagyobb egységekbe, nemzetségekbe - az úgynevezett halákba (kín. hala 哈拉) vagy halamukūnokba (kín. hala-mukun 哈拉穆昆) - tagolódnak. ${ }^{4}$

A sibék lélekszáma ma alig valamivel több mint 190000 före tehető. Döntő többségük (mintegy 143000 fö) Kína északkeleti tartományaiban él elszórtan, de az északnyugat-kínai Xinjiang Ujgur Autonóm Területen (kín. Xinjiang Weiwu'er Zizhiqu 新疆维吾尔自治区) belül ugyancsak nagyobb lélekszámú (kb. 34000 fönyi) közösségeik találhatók. Itt él Guan Wenming 矢文明 sibe autodidakta történész is.

Guan Wenming háza a xinjiangi Chabucha'er Sibe Autonóm Járás (kín. Chabucha'er Xibo Zizhixian 察布查尔锡伯自治县; si. Cabcal Sibe Beye Dasangga Siyan) történelmi falvainak egyikében, az Ötödik faluban

1 Tanulmányom a Magyar Tudományos Akadémia Prémium Posztdoktori Kutatói Program PPD-009/2017-es számú projektjének keretében készült.

2 A sibe szó az adott etnikum nevének mandzsu/sibe nyelvü írott formája. Maguk a sibék a szót ma śivənek ejtik (Zikmundová 2013: 10).

3 A sibe nyelvet - a mandzsu nyelv és írásrendszer megreformálásának köszönhetően 1947 óta különböztetik meg hivatalosan a mandzsutól („Xibozu Jianshi” Bianxiezu „Xibozu Jianshi” Xiudingben Bianxiezu 2008: 137).

4 Shirokogoroff 1924: 17-19. 
(si. Sunjaci niru) áll. Ez a falu valahol félúton található a falvak sorában. Guan Wenming házához a falvakat összekötö, nyugat felé vezető útról - nem sokkal a falu határát jelző tábla után - észak felé kell letérni egy kis, poros földútra.

A ház, amelyben Guan Wenming akkor lakott, amikor megismerkedtem vele, ${ }^{5}$ az utcára nyíló vaskaputól jóval beljebb, az előkert veteményese mögött állt. A kékre festett falak mögött három szoba bújt meg: a délre néző bejárati ajtóval szemben a konyha volt található; attól jobbra a keleti, balra pedig a nyugati szoba nyílt. Guan Wenming ez utóbbi szobában lakott, és ott őrizte családfagyüjteményét is - egy nagy, kék színü, csatos bőröndben, amelyet annak az ágynak a szélén tárolt, amelyen aludt. Ez a gyüjtemény volt az ő legféltettebb kincse, és Guan Wenming mindennél jobban szerette volna, hogy az megjelenhessen, mindenki számára hozzáférhetővé téve a xinjiangi sibék körében gyüjtött családfák anyagát.

A gyüjtemény értékét növeli az is, hogy a sibék családfaíró hagyománya 2009 óta hivatalosan is a sibe szellemi kulturális örökség részét képezi. Emiatt Guan Wenming munkásságát mind az autonóm járási, mind tartományi szinten egyre nagyobb figyelem övezi. A Guan Wenminggel való találkozásunk óta azonban már hat év eltelt, de a gyüjtemény még mindig nem látott napvilágot. ${ }^{6}$ Időközben a házat is, amelyben Guan Wenming egykor lakott, lebontották; a családja újat épített helyette. A gyüjtemény pedig dobozok mélyére került - egészen 2017 öszéig.

Akkor a Magyar Tudományos Akadémia Bölcsészettudományi Kutatóközpont Néprajztudományi Intézetének, illetve a Xinjiangi Tanárképző Főiskola Etnológiai és Szociológiai Intézetének (kín. Xinjiang Shifan Daxue Minzuxue Shehuixue Xueyuan 新疆师范大学民族学与社会学学院) intézményes hátterével Chabucha'erba utaztam, hogy Guan Wenming kérésére a teljes gyüjteményről fotódokumentációt készítsek. Ez volt az első lépés ahhoz, hogy a Guan Wenminggel való együttmüködésünk eredményeként publikálásra elökészítsük a gyüjteményt. E tanulmány feladata, hogy - segítve a tervezett forráskiadványhoz írt bevezető tanulmány átgondolását - feltárja a Guan Wenming családfagyüjtemény jelentőségét, röviden bemutassa annak tartalmát, és megvitassa annak jövőjét.

5 Guan Wenminggel 2012-ben, a 2010 óta - kisebb-nagyobb megszakításokkal, de mind a mai napig folyó kulturális antropológiai terepmunkáim során ismerkedtem meg.

6 Mindennek okára a tanulmányomhoz írt befejezésben még visszatérek. 


\section{A sibék és családfáik}

Az első történeti forrásmunkák, amelyek megemlítik a sibe nevet, 1593-ból, a kilenc törzs háborúja (kín. jiu bu zhi zhan 九部之战) kapcsán maradtak ránk. E háborút a sibék - nyolc másik szövetségessel együtt - a mandzsu Qingdinasztia (kín. Qing chao 清朝; man. Daicing gurun; 1644-1911) alapjait megvető Nurhacsival (kín. Nu'erhachi 努尔哈赤 man. Nurhaci; ur. 1616-1626) szemben vívták. ${ }^{7}$ És bár a háborúban a sibék a vesztes oldalon álltak, a hadjáratnak köszönhetően felléphettek a történelem színpadára.

A kilenc szövetséges leverése után kezdődött meg a mandzsuk hatalmának alapját képező nyolczászlós hadsereg (kín. baqi 八旗; man. jakūn gūsa) felállítása, ahová a sibéket is besorozták. A hadseregbe sorozva a sibék nem csupán a mandzsu nyelvet, hanem - a mandzsu írásrendszer kidolgozása után (1629) - a genealógiák szerkesztésének hagyományát is megörökölték. 1735-ben ugyanis maga Qianlong császár 乾隆 (ur. 1736-1795) adta parancsba a nyolczászlós hadseregben szolgálatot teljesítő katonák, illetve tisztviselők leszármazási vonalának az összeírását. ${ }^{8}$ Nem titkolt célja a mandzsu identitás megerősítése és a származás bizonyíthatósága volt. Ez utóbbira azért volt szükség, hogy a nyolczászlós hadseregben szolgáló emberek rangjukat, illetve az adott tisztségek örökléséhez való jogukat igazolni tudják. ${ }^{9}$

A családfák szerkesztésének gyakorlata pedig idővel a nép körében is elterjedt. Ennek bizonyítékául Kangxi császár 康熙 (ur. 1662-1723) uralkodásának idejéből állnak rendelkezésünkre a legkorábbi forrásanyagok. ${ }^{10}$ Ebből az időből maradtak fenn az első példák az írott sibe családfákról is. ${ }^{11}$ Ezeket a családfákat - a sibék ma fellelhető családfáival egyetemben - formai tekintetben két csoportra lehet osztani: az általában vászonra írt feljegyzésleplekre (kín. pudan 谱单), illetve a könyvszerü formában vezetett feljegyzéskönyvekre (kín. pushu 谱书) (1. kép). Mandzsu/sibe nyelven ma mindezekre a booi durugan kifejezéssel utalnak, amely kifejezés a kínai jiapu 家谱, vagyis családfa / családi feljegyzések kifejezés mandzsu nyelvü tükörfordítása. ${ }^{12}$

7 Wu 2008: 20.

8 A könyv végül A nyolc zászlóbeli mandzsuk nemzetségeinek annotált feljegyzései címen 1744-ben készült el (lásd Hong 2002).

9 Li 2006: 3-4.

10 Li 2006: 1 .

11 Tongjia-Wen 2009: 144.

12 A családfák formáik mellett fajtájuk tekintetében is megkülönböztethetők egymástól, attól függően, hogy azok egy egész nemzetség vagy egy már ágazatokra bomlott nem- 


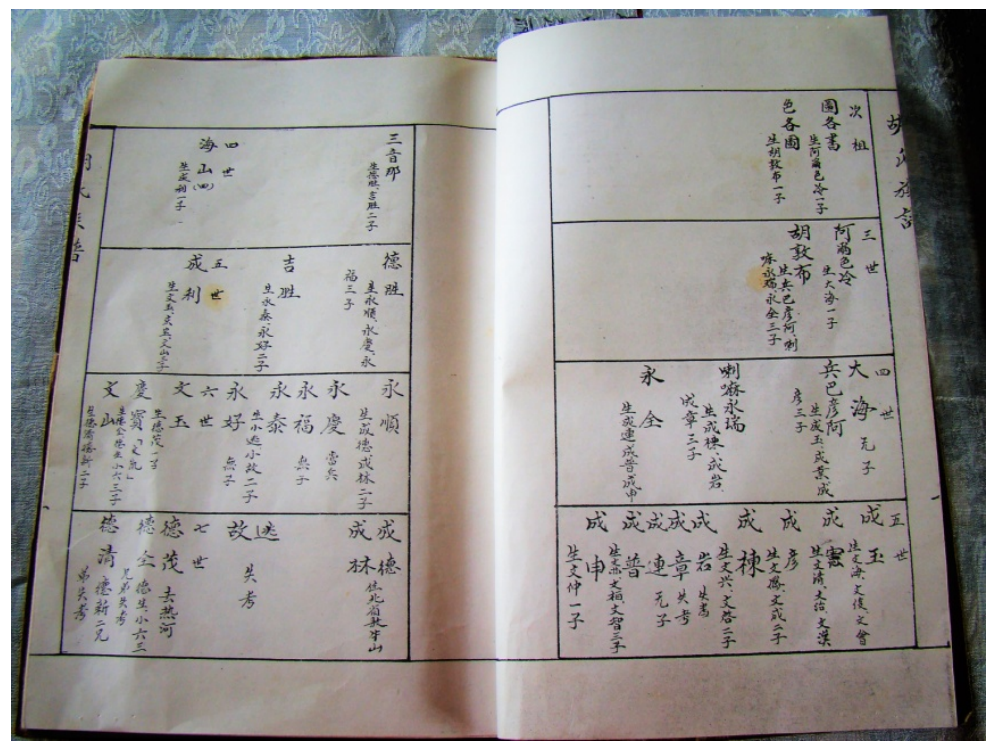

1. kép: Fotó az északkeleti Fushunban élö Hu család kínai nyelvü feljegyzéskönyvéröl (Liaoning, 2012. A szerzö felvétele)

Maguk a családfák a nemzetségek, illetve azok ágazatokra bomlását követően a nemzetségi ágazatok generációit sorszámozták az első adatolható őstől kezdve. ${ }^{13}$ Ugyanakkor az ősök nevei, a patrilineáris leszármazási vonal és a rokonsági kapcsolatok rendje mellett lejegyzésre kerülhetett még az adott nemzetségek, ágazatok története is, illetve a családfára feljegyzett emberek életrajzi adatai. Ezen kívül a családfákhoz úgynevezett családi törvényeket (kín. jiafa 家法) is kapcsolhattak, amelyek a helyes viselkedésmódot és a követendő normákat írták elő a nemzetségek, ágazatok tagjainak. Mindezeken felül a családfák olyan, idegen nemzetségi tagok elől elzárva tartott, tabuk által övezett tárgyak voltak, amelyek fontos szerepet töltöttek be a halottakra vonatkozó megemlékezések során is. ${ }^{14}$

A családfák tehát nem voltak mások, mint az ősökről őrzött tudás tárgyi hordozói. A családfaírás hagyományának szemszögéből ezért is jelentett olyan nagy törést, hogy 1764-ben a sibék egy részét Északkelet-Kínából a

zetségi ágazat leszármazási vonalát rejtik-e. A vonatkozó kérdéskört bővebben lásd Liu 1959: 25-26.

13 Gong 2002: 110.

14 Sárközi 2018: 60. 
mai Xinjiang vidékére telepítették, ${ }^{15}$ előidézve ezzel a sibéket ma jellemző sajátságos földrajzi eloszlást. Az áttelepítést követően ugyanis többé nem volt mód arra, hogy az egymástól elszakított nemzetségek, ágazatok megőrizzék a közös ősökre és a közös múltra vonatkozó tudást. ${ }^{16}$

Erre a tudásra az 1800-as évek végén a bokszerlázadás mérte a következő nagy csapást, amikor is számos - többek között sibe - nemzetség családfája odaveszett. ${ }^{17}$ A családfaírás hagyománya azonban mit sem veszített identitásformáló erejéből. Olyannyira, hogy az 1950-es években, miután a Kínai Kommunista Párt hatalomra került (1949) és a kínai nemzetépítés jegyében megkezdődött az etnikumok történelmének (re)konstruálása, a sibék történelmének megrajzolásában, illetve a sibe identitás újrafogalmazásában a megmaradt családfák és az azokon feljegyzett nemzetségi történetek felgyüjtése igen fontos szerepet játszott. ${ }^{18}$

Néhány évtized múltán, a nagy proletár kulturális forradalom (kín. Wuchanjieji Wenhua Dageming 无产阶级文化大革命) azonban a családfák elpusztításának újabb hullámához vezetett: az akkor megsemmisített családfák java részét a nemzetségek tagjai maguk égették el, vagy ásták el a föld mélyére félelmükben. Néhány családfa mégis túlélte az újabb pusztítást, és ezek a forradalom elmúltával újult erővel álltak ismét az ősökre vonatkozó, identitásformáló tudás felélesztésének a szolgálatába.

E tanulmány keretein belül nincs mód arra, hogy valamennyi, ezt alátámasztó forrást áttekintsek. Csupán példaként hozom fel a Shenyang xibozu zhi 沈阳锡伯族志 [A shenyangi sibék krónikája] címü könyvet, amelyben - félretéve a családfákat övező tabukat - tizenhét sibe nemzetség családfáját hozták nyilvánosságra az adott nemzetségek történetével egyetemben. ${ }^{19}$ Egy, már jóval később, Zhongguo xiboren 中国锡伯人 [A kínai sibe emberek]címen kiadott könyvet olvasva válik csak érthetővé, hogy e családfák felgyüjtése hogyan történt, és miként szolgálta a sibe identitás újrafogalmazását. ${ }^{20}$ De a sibék saját családfáik kutatása iránti érdeklődéséről sokat árul el az is, hogy a Shengjing yizhu Yili xibo ying xiang hong qi guanbing san dai ding ce

\footnotetext{
15 A ma nagy nyugatra telepités (kín. da xi qian 大西迁) néven ismertté vált eseményről bővebben lásd Sárközi 2018.

16 Tongjia-Wen 2009: 145.

17 A mandzsuk családfáit érintő pusztításról számol be például Shirokogoroff (1924: 62).

18 Sárközi 2018: 60.

19 Shenyang Shi Minwei Minzu Zhi Bianzuan Bangongshi 1988: 56-76.

20 Na Qiming - Han Qikun 2010: 10-101.
} 
盛京移驻伊犁锡伯营镶红旗官兵三代丁册 [A Shengjingbôl Ilibe települt sibe tábor keretes vörös zászlójába (besorozott) katonáinak három nemzedéket felölelö listája] címen 2003-ban megjelent könyv ${ }^{21}$ alapjául szolgáló eredeti kézirat olyan sok kézen forgott, hogy végül elveszett; a forráskiadvány is csupán egy fénymásolat alapján készülhetett el.

Mindezek a források azt bizonyítják, hogy maguk a családfák az ősökröl őrzött tudás hordozóiként milyen fontos szerepet játszottak - és játszanak mind a mai napig is - a sibe identitás életben tartásában. Mégsem hallgathatjuk el azt a tényt, hogy a családfákra mért pusztításokkal természetszerüen velejáró felejtés folyamata visszafordíthatatlan. Hivatalos jelentések szerint mára mindössze 111 sibe családfa maradt fenn, ${ }^{22}$ és bár számos sibe nemzetség fog bele ma is saját családfájának újraírásába, sokuk leginkább csak az öregek emlékezetére hagyatkozhat.

A családfákat ért pusztítás pedig nemcsak az 1764-ben egymástól elsodródott nemzetségekről, de sok helyütt az egyazon földrajzi, lokális térben élő sibék közötti rokonsági szálakról őrzött tudást is elhomályosította. Mindez még az olyan viszonylag zárt közösségekre nézve is igaz, mint a Chabucha'er Sibe Autonóm Járás történelmi falvaiban élő sibéké. Ez az, amiben Guan Wenming családfaíró tevékenységének, mint a felejtés elleni küzdelem egyik megnyilvánulási formájának jelentősége rejlik.

\section{Guan Wenming}

Guan Wenming 1938-ban született Xinjiangban, a mai Chabucha'er Sibe Autonóm Járásban. „A Gūwargeya ${ }^{23}$ nemzetségből való vagyok, szegény földmüves (kín. pinnong 贫农) családba születtem" - mondta 2012-ben, amikor még az első interjúfelvételeket készítettem vele. ${ }^{24}$ „Apám mikor született, azt én nem

21 Xinjiang Shaoshuminzu Gujiban - Beijing Shi Minwei Gujiban 2003.

22 He et al. 2009.

23 A sibék ma használt, kínai nyelvű családneveit legtöbbször a mandzsu/sibe nemzetségnevek első szótagjából képzik. Guan Wenming sibe nemzetségnevéből is így lett kialakítva a Guan kínai családnév.

24 Az itt lejegyzett életrajz a 2012 novemberében felvett hanganyag alapján készült el. Az életrajz megírásához fontos forrásként szolgált számomra továbbá egy 1988-as formanyomtatvány is, amelyen Guan Wenming felvételét kérte egy kínai népmüvészeti társaság bizottságának a tagjai közé. Ezen a nyomtatványon Guan Wenming családi háttereként a „szegény földműves” kifejezés lett feltüntetve; ez a kifejezés zömében 
tudom. [...] Az apám már meghalt, mikor én még anyám hasában voltam. Így én nem találkoztam saját apámmal" - folytatta, de a gyermekkorát tekintve sok minden homályos maradt.

Csupán annyi tekinthető bizonyosnak, hogy - amint az a fenti interjúrészletből is kiderül - az édesapa nagyon korán meghalt. Így Guan Wenming, aki a legkisebb gyermek volt a családban, félárvaként nevelkedett. Általános iskolai tanulmányait 1947 őszén, kilenc évesen kezdte meg. 1952 júliusa és 1953 augusztusa között Xinjiang tartományi székhelyén, Wulumuqiban 乌鲁木齐, a Kínai Kommunista Párt Központi Bizottsága Xinjiangi Hivatalának Káderképző Iskolájában (kín. Zhong Gong Zhong Yang Xinjiang Fenju Ganbu Xuexiao 中共中央新疆分局干部学校) tanult. Itt, emlékei szerint, a második legjobb tanuló volt:

„Egyszeriben levizsgáztam. Akkortájt az iskola kívánalma [az volt]: ha sibe nyelven írod [a vizsgát], az is jó, ha kínai nyelven, az is jó. Akkoriban én kínaiul nem értettem. [...] Kínaiul beszélni sem nagyon tudtam. Mikor odamentem. Ez bizony így volt. Aztán utána, ahogy levizsgáztam, azon a nyomtatványon - ha értetted a tartalmát, máris jó [volt]. 99\%-os lett [a vizsgám].”

Az iskola befejeztével Guan Wenming 1953 augusztusában tért haza szülőfalujába, és beosztása szerint 1954 decemberéig a párt ifjúsági tisztviselőjeként

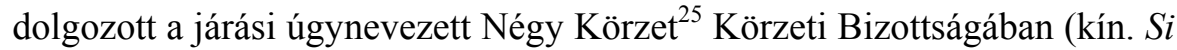
$Q u Q u$ Weihui 四区区委会). 1955-ben, mindössze 17 évesen a Chabucha'erhoz közeli Yining 伊宁 városi Xinhua Könyvesboltban (kín. Xinhua Shudian 新华书店) a könyvek forgalmazásáért felelős munkatársként kezdett dolgozni, majd 1958 és 1960 között a Xinjiangi Vas- és Acélgyárban (kín. Xinjiang Gang Tie Chang 新疆钢铁厂) helyezkedett el.

Ezt követően azonban, még a kulturális forradalom előtt otthagyta a várost. Mint mondta: „Hazatértem a saját otthonomba. Mondták, hogy valahol elhelyeztek volna. Oda én nem mentem. Ugyanaz, nem? Hát nincs rendjén, hogy visszajöjjek a saját öreg földemre?” Így történt, hogy Guan Wenming 1960-ban visszatért a Chabucha'er Sibe Autonóm Járásba; földet müvelt, és az Ötödik

azokra az emberekre utalt, akiknek nem volt saját földjük (vagy csak nagyon kevés földjük volt), és akik így bérbe vett földeken termelték meg mindennapi betevőjüket.

25 Az elnevezés Guan Wenming szülöfalujának egykori közigazgatási besorolására utal. 
falut ezután nem hagyta el. 1964 és 1968 között a falujától délnyugatra található Apa'er-csatorna (kín. Apa'er ganqu 阿帕尔干渠) vizének elosztásáért felelt, majd 1972-ig disznótenyésztéssel foglalkozott.

A mindennapi megélhetést biztosító munkák mellett Guan Wenming ifjúkorától kezdve nagy érdeklődést mutatott saját etnikumának története iránt. A legkülönfélébb történeti anyagok és a xinjiangi sibe családfák felgyüjtését már a kulturális forradalom elött megkezdte. De a „forradalom idején mindet elvitték"- mondta, és mikor megkérdeztem, ki vitte el, így folytatta:

„Óóóói, hát a vörösgárdisták. Ez nem egy ember műve volt. Ök vitték el. [...] A könyveim mind jó könyvek voltak. [...] Eredetileg a mi Ötödik falunkban egyetlen ember sem tudott [róluk]. Volt nekem az a könyvem, azt kölcsönadtam. De aztán ki tudja, hogy történt... Ez a könyv honnan van?" [Idézte fel az akkor elhangzott párbeszédet, majd hozzátette:] „Így történt. [...] Mindet elvitték.”

Mindez azonban nem szegte Guan Wenming kedvét. A forradalom elmúltával újrakezdte munkáját, és ma házában számos, a xinjiangi sibék történetét és vallását érintő, saját gyüjtésen alapuló, sibe nyelven írt kéziratot őriz. Ötvenhét mappába rendezett, mandzsu/sibe és kínai nyelveken írt családfagyüjteménye is több évtizedes munka eredménye: azon túl, hogy a forradalom során szinte a teljes családfagyüjteménye odalett, és újra kellett kezdenie azok felgyüjtését, egy-egy, a sibe nemzetségek által tabuként őrzött, generációról generációra áthagyományozott családfa felkutatásával, illetve a dokumentálás jogának kivívásával olykor éveket töltött el. Így, bár gyüjteménye zömében nem eredeti családfákat tartalmaz, azok értékes - és sokak számára hozzáférhetetlen - forrásai a sibék történelmére és családfáira irányuló kutatásoknak.

\section{Guan Wenming családfagyüjteménye}

Guan Wenming családfagyüjteményének összeállításakor háromfajta forrásra támaszkodott. Első és legfontosabb forrásai a xinjiangi sibék által örzött családfák, illetve ezek hiányában azok az úgynevezett háttérdokumentumok voltak (2. kép), amelyeket a sibék - az öregemberek emlékezetére hagyatkozva - a kulturális forradalom után vetettek papírra. Ilyen háttérdokumentumok mind az északkeleten, mind a Xinjiangban élő sibék körében fellelhetők. Ugyancsak 
fontos forrásnak bizonyultak Guan Wenming számára a temetőkben felállított sírkövekre vésett szövegek. Forrásai harmadik csoportját pedig azok a nyomtatásban megjelent dokumentumok alkották, amelyek a sibe nemzetségnevek számbavételét tüzték ki célul, ${ }^{26}$ választ keresve az azonos vagy hasonló nemzetségnevet viselő nemzetségek, ágazatok közötti feltételezett rokoni kapcsolatok kérdésére.

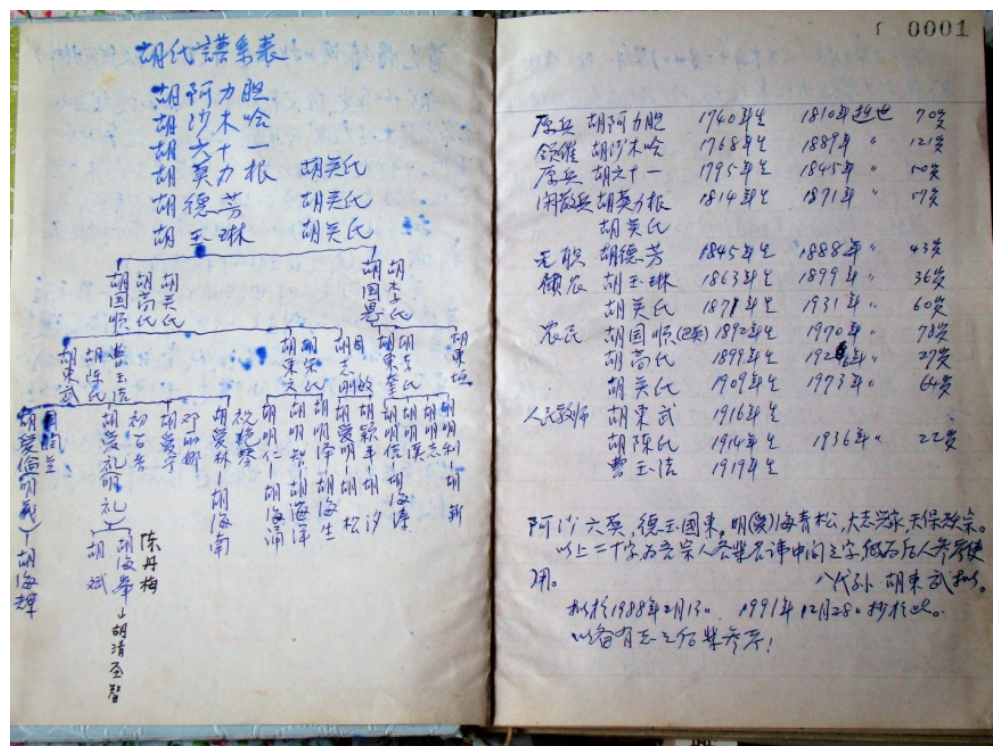

2. kép: Fotó a shenyangi Hu család tagjai által irt háttérdokumentumról (Liaoning, 2012. A szerzö felvétele)

Ennek hátteréül fontos tudni, hogy vannak olyan sibe nemzetségnevek, amelyek nagyon hasonlóak - mint például a Gūwargiya és a Guwalgiya, illetve a Hūsihari és a Hūsihar nemzetségnevek. Sok esetben azonban ma már nem lehet tudni, hogy adott, egymáshoz olyannyira hasonló nemzetségnevek egy és ugyanazon nemzetségeket jelölik-e. ${ }^{27} \mathrm{Az}$ is előfordulhat, hogy egy és ugyanazon nemzetségnévhez többféle kínai családnév társítható; így például a Hashūri nemzetségnév egyaránt megfeleltetethető a Ha 哈 és a Han 韩 kínai családneveknek. És hasonlóképpen: ugyanaz a kínai családnév különböző nemzetségekre utalhat; a Tong 佟 kínai családnevet például egyaránt viselhetik

\footnotetext{
26 Lásd pl. Gong 2002; Zhao-Wu 2008: 194-217.

27 Zhao-Wu 2008: 199.
} 
a Tukseri és a Tumurci nemzetségek tagjai. A problémát pedig tovább bonyolítja, hogy vannak nemzetségnevek, amelyekkel kapcsolatban nem világos, hogyan is ültették át őket kínai nyelvre; mint ahogyan vannak olyan kínai családnevet viselő sibe nemzetségek is, amelyekről - mandzsu/sibe nyelvü családfáik híján - nem tudni, milyen nemzetségnevet viseltek egykoron.

Mindezek a problémák a családfák elvesztéséből, a nyelv fokozatos elfelejtéséből és az eredetileg több szótagú mandzsu/sibe nemzetségnevek egy szótagú, kínai nyelvü családnevekre való átültetéséből fakadnak. ${ }^{28}$ Így fordulhat elő, hogy például, ha egy északkeleten élő, Tong kínai családnevet viselő nemzetségnek nem volt lehetősége megőrizni mandzsu nyelvü családfáját, nem tudhatja, hogy nemzetségének eredetileg mi volt a nemzetségneve. És mivel a Tong családnevet Xinjiangban több nemzetség is viselheti - mint például a Tukseri és a Tumurci nemzetségek -, a válaszkereséshez az e nemzetségekkel való kapcsolatfelvétel sem vinne közelebb. Ráadásul a régi nemzetségi családfák elvesztése miatt sokszor az azonos nemzetségnevet viselő nemzetségek, ágazatok közötti kapcsolat sem világos.

A fentebb ismertetett források használatával készült el tehát a családfagyüjtemény, amelyet Guan Wenming 57 mappába rendezett. A mappák a Chabucha'er Sibe Autonóm Járásban fellehető Első (si. Uju niru), Harmadik (si. Ilaci niru), Negyedik (si. Duici niru), Ötödik (si. Sunjaci niru), Hatodik (si. Ningguci niru), Hetedik (si. Nadaci niru) és Nyolcadik (si. Jakūci niru) faluban élő vagy onnan származó sibe nemzetségek körében gyüjtött anyagokat tartalmazzák. Ezek az anyagok három csoportba sorolhatók: a Guan Wenming elött feltárt, adott nemzetségek által őrzött családfákról írt piszkozatokra (3. kép); a piszkozatokról készített - és sokszor továbbírt, bővített, a leszármazást a jelenkorig vezető - tisztázatokra (4. kép); illetve a mindezekhez csatolt rövid bevezetőkre. A bevezetőkben általában a nemzetségek nevéröl és északkeleti lakhelyéröl olvashatunk - vagyis arról, hogy az adott nemzetség az áttelepítés előtt a nyolczászlós hadsereg melyik zászlajában szolgált és hol élt. Ezek az információk - amelyeket Guan Wenming elmondása szerint az eredeti családfákon látott - különösen fontosak lehetnek a nemzetségek történetének rekonstruálása szemszögéből.

28 Ez a folyamat az északkeleten élő sibék körében sokkal korábban zajlott le, mint a xinjiangi sibéknél. A családfákon feltüntetett nevek vizsgálata segíthet teljesebb képet rajzolni erröl a folyamatról is. 
A kéziratok zömében mandzsu/sibe nyelven íródtak. A gyüjtemény sajátossága, hogy Guan Wenming a családfák bővítésekor a már kínai családés utóneveket is sibe nyelven jegyezte fel. A kínai nyelvü feljegyzések a legtöbb esetben csupán kiegészítői a mandzsu/sibe nyelven írt családfáknak. Ugyancsak a gyüjtemény sajátosságai között kell megemlítenem, hogy a családfákon - szemben a hagyományos gyakorlattal - sok helyütt a nemzetségek, ágazatok női leszármazottainak, illetve a nemzetségbe házasodó asszonyok nevét is feljegyezték.

A gyüjteményben fellehető kéziratok oldalszáma összesen 641-re tehető. Ez a szám a fenti anyagokon túl magába foglalja még az eredeti, a leszármazást megrajzoló családfákról készített fénymásolatokat, illetve az eredeti, adott nemzetségektől gyüjtött, feljegyzéskönyv-formájú családfákat is. A gyüjteménynek hasonlóan értékes - és a 641 oldalnyi kézirat közé sorolható - részét képezik továbbá az eredeti családfák mellé csatolt nemzetségtörténetekröl és családi törvényekről készített kéziratos másolatok is. Mindezeken kívül az 57 mappában találhatunk még 27 úgynevezett feljegyzéslepel-formájú családfát is. Ezeknek kis része másoktól gyüjtött, fénymásolt anyagot takar; többnyire azonban Guan Wenming maga készítette ezeket több, egymáshoz ragasztott papírlapra, amelyek hossza így több métert is kitesz.

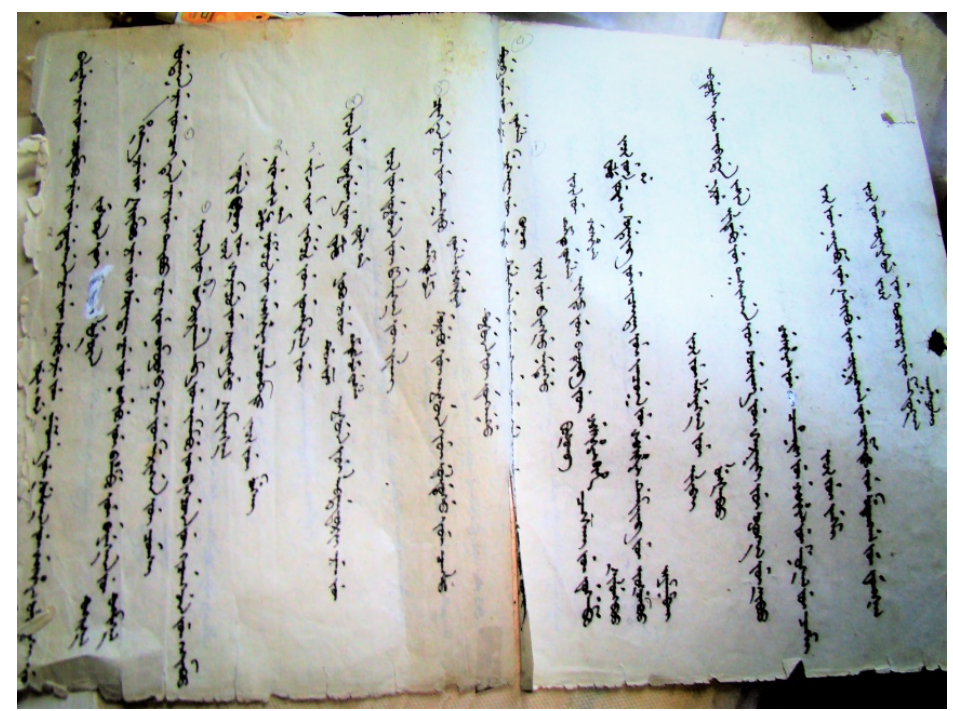

3. kép: Egy példa Guan Wenming gyüjteményéből az eredeti családfákról készitett kéziratos másolatról. A sibe nyelvü szöveg egy xinjiangi sibe nemzetség családfájának a részletét takarja (Xinjiang, 2017. A szerzö felvétele) 


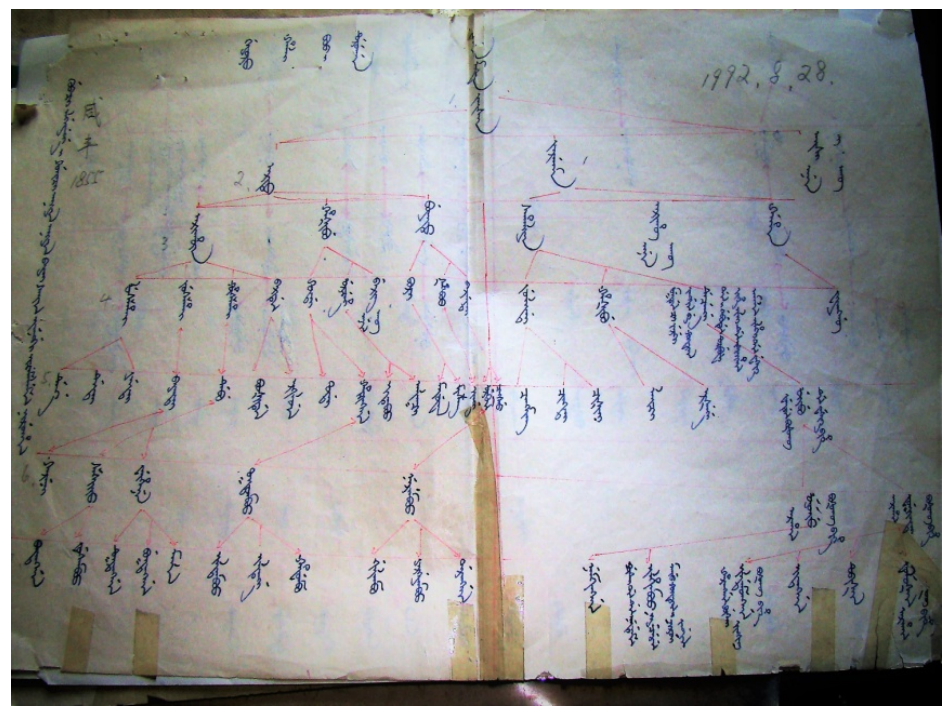

4. kép: Egy példa Guan Wenming gyüjteményéböl az eredeti családfákról készitett tisztázatra. A sibe nyelvü családfán egy xinjiangi sibe nemzetség ágazatainak a rajzolata látható. A kézirat bal oldalán futó sibe nyelvü irás az eredeti családfa elkészitésének idejéröl tájékoztat. A felsö, négysoros sibe szöveg azt tisztázza, hogy a családfa melyik sibe nemzetség tulajdona. A jobb felső sarokban a tisztázat elkészitésének dátuma látható (Xinjiang, 2017. A szerzö felvétele)

Az ötvenhét mappa anyaga röviden áttekintve sorrendben a következö: ${ }^{29}$

1. mappa: A mappa két, Guan Wenming kutatásai szerint egymással öszszefüggésbe hozható nemzetség családfáját tartalmazza. Az első családfa az Első falubeli Tungjiya nemzetségé, ${ }^{30}$ amelynek ,első őse” ${ }^{, 11}$ Erhetu. A második családfa a Harmadik falubeli Tuksuri nemzetségé, amelynek „első őse” Alenai.

2. mappa: A családfa az Első falubeli Guwalgeya nemzetségé, amelynek „első őse" Sidebu.

29 A mappák sorszámozása Guan Wenming rendszerezését követi.

30 Guan Wenming a gyüjteményen belül nem tesz különbséget a között, hogy egy adott mappában valóban egy nemzetség vagy csupán egy nemzetségi ágazat családfáját közli-e; a családfák birtokosairól minden esetben mint nemzetségről beszél.

31 Guan Wenming gyüjteményében az „első ős” kifejezés nem mindig és nem feltétlenül az Ilibe áttelepülő nemzetségi ősre utal. Olykor csak a családfára írt nemzetségtörténeti feljegyzések teszik egyértelművé, hogy az adott név még az északkeleten élő ősre vagy a már Iliben letelepedett ősre utal-e. 
3. mappa: Az Első falubeli Gūwargeya nemzetség családfája, amelynek „első őse” Nayantai. A nemzetség mind a Negyedik, mind az Ötödik falubeli, hasonló nemzetségnevet viselő nemzetségekkel összefüggésbe hozható.

4. mappa: A családfa az Első falubeli Erkele nemzetségé, amelynek ,első őse" Lungtu. Az eredeti, 1903-ban állított családfáról Guan Wenming a mappában található piszkozatot 1987-ben készítette.

5. mappa: Az Első falubeli Yungtur nemzetség családfája, az „első ős” neve Bahai.

6. mappa: Az Első falubeli Hūshar nemzetség családfája, amelynek ,első őse” Lederi. A mappában található, 1987-ben írt piszkozatot Guan Wenming a nemzetség 1881-ben állított családfája alapján készítette.

7. mappa: A Harmadik falubeli Gorolo nemzetség családfája, amelynek „első őse” Nomun Hordi volt.

8. mappa: A Harmadik falubeli Šumur nemzetség családfája; a nemzetség „első őse” Fulhan. A mappában található piszkozatot Guan Wenming 1986-ban írta. Az eredeti családfát 1879-ben állították fel.

9. mappa: A Harmadik falubeli Tungjiya nemzetség családfája.

10. mappa: A Harmadik falubeli Anjiya nemzetség családfája; az „első ős" neve Arselan.

11. mappa: A Negyedik falubeli Yangjiri nemzetség családfája.

12. mappa: A Negyedik falubeli Hū Hū Ci nemzetség családfája; a nemzetség „első ősének” neve Tumuci.

13. mappa: A Negyedik falubeli Korot nemzetség családfája. A családfa három ős, Ulintai, Jamcu és Jahūstai ágazatait vezeti végig a hetedik generációig.

14. mappa: A Negyedik falubeli Joo nemzetség családfája, amelyet Guan Wenming 1974-ben, a kulturális forradalom idején vetett papírra.

15. mappa: A Negyedik falubeli Tungjiya nemzetség családfája. Ezt a nemzetséget Guan Wenming összefüggésbe hozza az első és a kilencedik mappába sorolt nemzetségekkel. A családfa a Hoto nevü ős négy utódjának ágazatát ismerteti.

16. mappa: A Negyedik falubeli Guwargeya nemzetség családfája.

17. mappa: A Negyedik falubeli Gūwargeya nemzetség családfája, amely egy, a nemzetségi tagok által 1982-re befejezett, sibe nyelvü, „feljegyzéskönyv"-formájú családfát takar.

18. mappa: A Negyedik falubeli Gūwargeya nemzetség családfája, amelynek piszkozatát Guan Wenming 1995-ben írta. A piszkozat az 1941-ben írt családfa alapján készült. 
19. mappa: Az Ötödik falubeli Gūwargeya nemzetség családfája; a nemzetség ,első őseként” az a Nayantai kerül megnevezésre, akit az Első falubeli Gūwargeya nemzetség is 'első őseként' említ.

20. mappa: Az Ötödik falubeli Guwargeya nemzetség családfája. A történeti bevezetések valamennyi, a családfára jegyzett ágazat őseként Burencit nevezik meg.

21. mappa: Az Ötödik falubeli Cunjir nemzetség családfája, amelyen az 1862-ben született Folocuntól származtatott ágazatok szerepelnek.

22. mappa: Az Ötödik falubeli Anjiya nemzetség családfája; a nemzetség ágazatai Nakculaitól származtathatók. A nemzetségtörténeti feljegyzések szerint az eredeti családfát 1893-ban írták.

23. mappa: Az Ötödik falubeli Anjiya nemzetség eredetileg 1893-ban írt családfája.

24. mappa: Az Ötödik falubeli Heyer nemzetség családfája, amely a három őstől, Mulintól, Deletől és Šagencuntól származtatható ágazatokat vezeti végig.

25. mappa: Az Ötödik falubeli Heyer nemzetség családfája.

26. mappa: Az Ötödik falubeli Heyer nemzetség családfája. A gyüjtött anyag Golminggát nevezi meg a nemzetség „első ősének”.

27. mappa: A mappa három, különbözö nemzetség - vagy inkább ágazat befejezetlen családfáját tartalmazza. Az első a Lungtu nevü „első őstől” származtatható Heyere nemzetségé; a második a Jingsintai nevü „,nagyapától” származtatható Tungjiya nemzetségé; a harmadik a Beji nevü őstől származtatható Walkara nemzetségé (412-413).

28. mappa: Az Ötödik falubeli Hūsihari nemzetség családfája; a nemzetség ,nagy őse" Hūlang.

29. mappa: Az Ötödik falubeli Tokori nemzetség családfája; a nemzetség „első őse” Mergen volt. A Guan Wenming által másolt családfa eredetijét 1903-ban írták.

30. mappa Az Ötödik falubeli Bayara nemzetség családfája; a nemzetség Daracuntól származtatja ágazatait. Az eredetileg a XIX. század elején állított családfáról Guan Wenming 1995-ben készítette piszkozatát.

31. mappa: Az Ötödik falubeli Ujala nemzetség családfája; a mappában őrzött kéziratokon belül a nemzetség neve Ujalaként és Ujarként is megtalálható.

32. mappa: Az Ötödik falubeli Ujala nemzetséghez tartozó ágazatok családfája.

33. mappa: A Hatodik falubeli Hashūri nemzetség családfája; a nemzetség tagjai már igen korán, az 1980-as években egyesítették nemcsak chabucha’eri, 
hanem északkeleti ágazataikat is. Egészen a 2000-es évek elejéig ez volt az egyetlen sibe családfa, amelyen sikerült kimutatni egy egymástól 1764-ben elszakított sibe nemzetség együvé tartozását. ${ }^{32}$

34. mappa: A Hatodik falubeli Bayara nemzetség családfája; a nemzetség Ilibe áttelepülő őse Arbin volt.

35. mappa: A Hatodik falubeli Gonggoro nemzetség családfája; a nemzetség Keksebutól származtatja ágazatait.

36. mappa: A Hatodik falubeli Nara nemzetség családfája, amelyre három őstől származtatható ágazat lett felvezetve. Egyikük a leghíresebb sibe sámánok egyike, Elsi sámán. A negyedik, velük azonos generációhoz tartozó ősnek nem születtek utódai.

37. mappa: A Hatodik falubeli Han Jir nemzetség családfája; a nemzetséget Cohotaitól származtatják.

38. mappa: A Hatodik falubeli Fuca nemzetség családfája. Guan Wenming az 1994-ben papírra vetett, a mappában megtalálható piszkozatokat feltehetően az 1962-ben újraírt családfa alapján állította össze. A nemzetség „első ősének” neve Etei.

39. mappa: A Hatodik falubeli Jashūri vagy Jashūr nemzetség - a családfán mindkét névváltozat előfordul - családfája.

40. mappa: A Hatodik falubeli Geyoro nemzetség családfája, amelynek ágazatai Marjitól és Dejintől származtatják magukat.

41. mappa: A Hetedik falubeli Geyoro nemzetség családfája, amely a Nesunggától származtatható nyolc ágazatot mutatja be.

42. mappa: A Hetedik falubeli Kunggere nemzetség családfája; a családfán feljegyzett „első ös” neve Šokto volt.

43. mappa: A Hetedik falubeli Yehe Nara nemzetség családfája. A mappában található anyagokat Tongjia Qingfu 佟加 庆夫 sibe néprajztudós fordította le kínai nyelvre.

44. mappa: A Hetedik falubeli Ayara nemzetség családfája, amelyen két ős, Amidari és Garama ágazatai rajzolódnak ki. Az eredeti családfát 1885-ben állították.

45. mappa: A Nyolcadik falubeli Jashūri - vagy Jasihūri - nemzetség családfája. Az eredeti családfát 1878-ban állíthatták fel; az arról készített piszkozatot Guan Wenming 1993-ban írta.

32 A nemzetség „családfa-egyesítő” történetét teljes egészében lásd Sárközi 2018: 143-168. 
46. mappa: A Nyolcadik falubeli Guwalgeya nemzetség családfája, amely a nemzetség négy nagy ágazatát vezeti le: Siderhe, Šerengge, Tacibu és Suyengge ágazatait.

47. mappa: A Nyolcadik falubeli Guwalgeya nemzetség családfája, amelynek piszkozatát Guan Wenming 1987-ben vetette papírra. A piszkozat alapjául szolgáló eredeti dokumentumot 1919-ben írhatták.

48. mappa: A Nyolcadik falubeli Guwargeya nemzetség családfája, amely az Ilibe települö „első ős”, Silimboo ágazatát mutatja be.

49. mappa: A Nyolcadik falubeli Ujar nemzetség családfája; a nemzetség ösének neve Arana.

50. mappa: A Nyolcadik falubeli Ujala nemzetség Mahūdától és Karanától származtatható ágazatainak családfája.

51. mappa: A Nyolcadik falubeli Bayar nemzetség családfája; a nemzetség „első őse” az az Arbin volt, akit a Hatodik falubeli Bayara nemzetség is „első őseként” tart számon.

52. mappa: A Nyolcadik falubeli Tokori nemzetség családfája, amelynek eredetijét 1903-ban állították. A nemzetség „első őse” az a Mergen volt, akit az Ötödik falubeli Tokori nemzetség is „első ősének” tekint.

53. mappa: A Nyolcadik falubeli Fuca nemzetség családfája; a nemzetség Ilibe áttelepülő „első őse” Sergine volt. Az eredeti családfát 1901-ben állították.

54. mappa: A Nyolcadik falubeli Geyoro nemzetség családfája, amelynek piszkozatát Guan Wenming 1992-ben vetette papírra. Az eredeti családfát 1855-ben állították.

55. mappa: A Nyolcadik falubeli Gorgi nemzetség családfája, amely az Ilibe áttelepülő ős, Ahūngga két fiának ágazatát, Ahali és Doho leszármazottainak nevét vezeti le. A piszkozatot Guan Wenming 1990-ben írta; az eredeti családfát 1891-ben állították.

56. mappa: A Nyolcadik falubeli Ilari nemzetség családfája; a nemzetség „első öse” Hobitu volt.

57. mappa: A Nyolcadik falubeli Šigeya nemzetség családfája, amelyen négy ős, Erhujui, Baldasi, Udana és Durbe ágazatai rajzolódnak ki. 


\section{Befejezés}

Kína 2004-ben csatlakozott a szellemi kulturális örökség programhoz, amelynek keretében a szervezett adatgyüjtési munkák 2007-ben kezdődtek meg. ${ }^{33}$ Guan Wenming családfaíró tevékenységére e program keretében figyeltek fel: a sibék családfaíró hagyománya 2009-ben lett a sibe szellemi kulturális örökség része, és ettől kezdve Guan Wenming családfagyüjteménye iránt mind nagyobb érdeklődés mutatkozott - többek között egy, a sibék családfaíró hagyományát bemutatni kívánó kínai nyelvü könyv megírása miatt.

Néhány évvel ezelött, az e könyv megszületéséről szóló határozat tartományi szintü elfogadtatása után egy sibe történészekből, néprajztudósokból és káderekből álló csoport kezdte meg a xinjiangi sibe családfák felkutatására irányuló kutatómunkáját a Chabucha'er Sibe Autonóm Járásban. A csoport megbízottjai Guan Wenminget többször is felkeresték, hogy családfagyüjteményébe betekintést nyerjenek és dokumentálják. Mivel azonban magába a munkafolyamatba nem kívánták őt bevonni, Guan Wenming nem egyezett bele az együttmüködésbe. Ekkor, ezért kért fel engem a közös együttmüködés reményében.

Közös munkánk célja eredetileg az lett volna, hogy rendszerezzük, ellenörizzük és szükség esetén kiigazítsuk, javítsuk a családfákra jegyzetteket. Egy ilyen volumenű munka azonban többéves kutatómunkát kívánna meg, amelyhez intézményes hátteret eddig egyetlen kínai intézmény sem tudott biztosítani. Így most az első és legfontosabb célunk, hogy a mind a mai napig a Guan Wenming által őrzött családfagyüjtemény forráskiadványként megjelenjen.

A forráskiadvány alapjául szolgáló kézirat már elkészült. Benne a mappák és a Guan Wenming-kéziratok közlésének sorrendje Guan Wenming rendszerezését követi, változtatás nélkül. A tervezett forráskiadványban a kéziratok latin betüs átírása mellett megtalálhatók lesznek a kéziratokról készített fotók is, amelyek mindegyike fölött egy több elemből álló kód lesz olvasható. E kódok a kéziratos lapok azonositását, azok fajtájának a megjelölését, illetve a rájuk való hivatkozást segítik majd.

Az így közreadott forráskiadvány, amely várhatóan a Magyar Tudományos Akadémia Bölcsészettudományi Kutatóközpont Néprajztudományi Intézetének gondozása alatt álló „Occasional Papers in Anthropology”-ban jelenik majd meg, fontos támpontként szolgálhat a sibék történelmét, társadalmát,

33 Tongjia-Wen 2009: 208. 
kultúráját és nyelvét érintő kutatásokhoz. És nem utolsósorban: egy sibe autodidakta történész életművének megértéséhez, feldolgozásához, rekonstruáláshoz és folytatáshoz.

MANDZSU/SIBE NYELVÜ SZÓSZEDET

\begin{tabular}{|c|c|}
\hline Ahali & 1mincinc \\
\hline Ahūngga & hinomid \\
\hline Alenai & 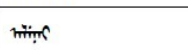 \\
\hline Amidari & मांक्या \\
\hline Anjiya & mनत्रl \\
\hline Arana & mat? \\
\hline Arbin & mot \\
\hline Arselan & mant \\
\hline Ayara & Imext \\
\hline Bahai & onis \\
\hline Baldasi & कीजिएक \\
\hline Bayar & 6 कार्र \\
\hline Bayara & का कात्रा \\
\hline Beji & $\dot{\theta}=5$ \\
\hline booi durugan & 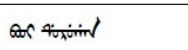 \\
\hline Burenci & 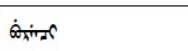 \\
\hline $\begin{array}{lcc}\text { Cabcal Sibe } & \text { Beye } \\
\text { Dasangga Siyan } & \end{array}$ & 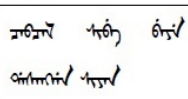 \\
\hline Cohotai & ग्राण्ण \\
\hline Cunjir & म्रान्तर \\
\hline Daicing gurun & 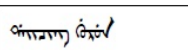 \\
\hline Daracun & किस्यं। \\
\hline Dejin & | \\
\hline Dele & । \\
\hline Doho & कीजिए \\
\hline Duici niru & किणना \\
\hline Durbe & संग्रुक \\
\hline Elsi & Hits \\
\hline Erhetu & भर्ती \\
\hline Erhujui & यकित्र \\
\hline
\end{tabular}

\begin{tabular}{|c|c|}
\hline Erkele & 年 \\
\hline Etei & $\sqrt{p^{\prime}}$ \\
\hline Folocun & tuiva्यil \\
\hline Fuca & tion \\
\hline Fulhan & Guation? \\
\hline Garama & मींग्रा' \\
\hline gargan & 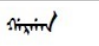 \\
\hline Geyoro & iिग्रण0 \\
\hline Golmingga & 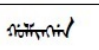 \\
\hline Gonggoro & 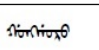 \\
\hline Gorgi & 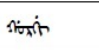 \\
\hline Gorolo & मींग्रणंड \\
\hline Guwalgeya & àtinisl \\
\hline Guwalgiya & ímints \\
\hline Guwargeya & किज्ञाint \\
\hline Gūwargeya & sisturingt \\
\hline Gūwargiya & 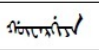 \\
\hline hala & now/ \\
\hline hala-mukūn & solied tionot \\
\hline Han Jir & $\sin \pi x$ \\
\hline Hashūri & मीकाषणित्र \\
\hline Heyer & 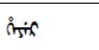 \\
\hline Heyere & (m) \\
\hline Hobitu & 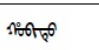 \\
\hline Hoto & $\mathrm{sim}_{0}$ \\
\hline Hū Hū Ci & 10 \\
\hline Hūlang & 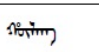 \\
\hline Hūshar & siom \\
\hline Hūsihar & Siorthming \\
\hline Hūsihari & 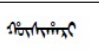 \\
\hline
\end{tabular}




\begin{tabular}{|c|c|}
\hline Ilaci niru & मान्म \\
\hline Ilari & $\min 5$ \\
\hline Jahūstai & rivionthrs \\
\hline Jakūci niru & 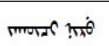 \\
\hline jakūn gūsa & mort ditorl \\
\hline Jamcu & 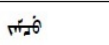 \\
\hline Jashūr & mhines \\
\hline Jashūri & minण \\
\hline Jasihūri & mhnणंणत्रr \\
\hline Jingsintai & mimmors \\
\hline Joo & ద \\
\hline Karana & in \\
\hline Keksebu & ) \\
\hline Korot & जिएक्रण \\
\hline Kunggere & CAmitil \\
\hline Lederi & 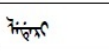 \\
\hline Lungtu & خैखिए \\
\hline Mahūda & मांगां। \\
\hline Marji & $b_{x \rightarrow r}$ \\
\hline Mergen & this \\
\hline Mulin & 说 \\
\hline Nadaci niru & فेंग \\
\hline Nakculai & 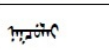 \\
\hline Nara & ?ריד \\
\hline Nayantai & 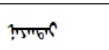 \\
\hline Nesungga & Hithinil \\
\hline Ningguci niru & 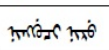 \\
\hline Nomun Hordi & 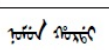 \\
\hline Nurhaci & फेगण \\
\hline
\end{tabular}

\begin{tabular}{|c|c|}
\hline Sergine & मित्रांते \\
\hline sibe & त्रु \\
\hline Sidebu & भिंकी \\
\hline Siderhe & 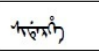 \\
\hline Silimboo & 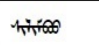 \\
\hline Sunjaci niru & 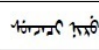 \\
\hline Suyengge & मिंगुणn \\
\hline Šagencun & animail \\
\hline Šerengge & 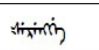 \\
\hline Sigeya & smind \\
\hline Šokto & जग़ाँ़ी \\
\hline Šumur & स光形 \\
\hline Tacibu & कात्राण \\
\hline Tokori & amoners \\
\hline Tukseri & 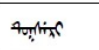 \\
\hline Tuksuri & Aughtors \\
\hline Tumuci & 4 furvas \\
\hline Tumurci & 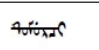 \\
\hline Tungjiya & 40ता \\
\hline Udana & 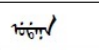 \\
\hline Ujala & कित्रो| \\
\hline Ujar & मित्रा \\
\hline Uju niru & סृ. \\
\hline Ulintai & भौज़ण \\
\hline Walkara & तोimeत्र \\
\hline Yangjiri & गाल \\
\hline Yehe Nara & sin \\
\hline Yungtur & $\sin 7 \pi x$ \\
\hline
\end{tabular}

\section{Elsődleges források}

Sárközi Ildikó Gyöngyvér 2018. Böröndbe zárt emlékezet. Guan Wenming sibe családfagyüjteménye. (Kiadatlan kézirat, MTA BTK Néprajztudományi Intézet; a kéziratot a Guan Wenming által gyüjtött és felajánlott anyagok alapján összeállította, illetve a bevezető tanulmányt írta: Sárközi Ildikó Gyöngyvér.) 


\section{Felhasznált másodlagos szakirodalom}

Gong Yichang 龚义昌 2002. Xibozu xingshi kao 锡伯族姓氏考 [A sibe nemzetségnevek vizsgálata]. Wulumuqi: Xinjiang Renmin Chubanshe.

He Yuanfu 贺元福 et al. 2009.,Xibozu zongpu wenhua yichan 锡伯族宗谱文化遗产 [A sibe családfák kulturális öröksége].” In: He Ling 贺灵 (ed.) Xibozu wenhua jingcui 锡伯族文化精粹 [A sibe kultúra esszenciája]. Wulumuqi: Xinjiang Renmin Chubanshe, 380-395.

Hong Zhou 弘昼 et al. (eds.) 2002. Ba qi manzhou shizu tongpu 八旗满洲氏族通谱 [A Nyolc Zászlóbeli mandzsuk nemzetségeinek annotált feljegyzései]. Shenyang: Liaohai Chubanshe.

Li Lin 李林 2006. Manzu zongpu yanjiu 满族宗谱研究 [Mandzsu családfák vizsgálata]. Shenyang: Liaoning Minzu Chubanshe.

Liu, Hui Chen-Wang 1959. The Traditional Chinese Clan Rules. Locust Valley, New York: J. J. Augustin Incorporated Publisher.

Na Qiming 那启明 - Han Qikun 韩启昆 (eds.) 2010. Zhongguo xiboren 中国锡伯人 [A kínai sibe emberek]. Shenyang: Liaoning Minzu Chubanshe.

Sárközi Ildikó Gyöngyvér 2018.A mártírium homályából: Sibe ösök és hösök a kínai nemzetépités oltárán. Budapest-Pécs: MTA BTK Néprajztudományi Intézet - PTE Néprajz - Kulturális Antropológia Tanszék - L’Harmattan.

Shenyang Shi Minwei Minzu Zhi Bianzuan Bangongshi 沈阳市民委民族志编纂办公室 (ed.) 1988. Shenyang xibozu zhi 沈阳锡伯族志 [A shenyangi sibék krónikája]. Shenyang: Liaoning Minzu Chubanshe.

Shirokogoroff, S. M. 1924. Social Organization of the Manchus. A Study of the Manchu Clan Organization. Shanghai: Royal Asiatic Society.

Tongjia Qingfu 佟加庆夫 - Wen Jian 文健 2009. Xibozu feiwuzhi wenhua yichan daibiaozuo 锡伯族非物质文化遗产代表作 [A sibe nemzetiség szellemi kulturális örökség-listája]. Wulumuqi: Xinjiang Renmin Chubanshe.

Wu Yuanfeng 吴元丰 2008.,,Qingchu xibozu juzhu quyu ji yu xianglin minzu de guanxi 清初锡伯族居住区域及与相邻民族的矢系 [A kora Qing-kori sibe nemzetiség lakhelye és a környezô nemzetiségekkel való kapcsolata].” In: Wu Yuanfeng 吴元丰 - Zhao Zhiqiang 赵志强 (eds.) Xibozu lishi tanjiu 锡伯族历史探究 [A sibe nemzetiség történelmének vizsgálata]. Shenyang: Liaoning Minzu Chubanshe, 15-24.

„Xibozu Jianshi” Bianxiezu, 锡伯族简史”编写组 - „Xibozu Jianshi” Xiudingben Bianxiezu，锡伯族简史”修订本编写组 (eds.) 2008. Xibozu jianshi 锡伯族简史 [A sibe nemzetiség rövid története]. Beijing: Minzu Chubanshe.

Xinjiang Shaoshuminzu Gujiban 新疆少数民族古籍办 - Beijing Shi Minwei Gujiban 北京市民委古籍办 (eds.) 2003. Shengjing yizhu Yili xibo ying xiang hong qi guanbing san dai ding ce 盛京移驻伊犁锡伯营镶红旗官兵三代丁册 [A Shengjingbôl Ilibe települt sibe tábor keretes vörös zászlójába [besorozott] katonáinak három nemzedéket felölelö listája]. Wulumuqi: Xinjiang Renmin Chubanshe.

Zhao Zhiqiang 赵志强 - Wu Yuanfeng 吴元丰2008. „Xibozu de xingming 锡伯族的姓名 [A sibe nemzetiség nemzetség- és adott neveiröl]”. In: Wu Yuanfeng 吴元丰 - Zhao 
Zhiqiang 赵志强 (eds.) Xibozu lishi tanjiu 锡伯族历史探究 [A sibe nemzetiség történelmének vizsgálata]. Shenyang: Liaoning Minzu Chubanshe, 194-217.

Zikmundová, Veronika 2013. Spoken Sibe: Morphology of the Inflected Parts of Speech. Prague: Charles University in Prague - Karolinum Press. 